\title{
The state of sustainable agriculture and agroecology research and impacts: A survey of U.S. scientists
}

\author{
Marcia DeLonge ${ }^{\mathrm{a}} *$ and Tali Robbins ${ }^{\mathrm{b}}$ \\ Union of Concerned Scientists
}

Andrea D. Basche ${ }^{\mathrm{c}}$

University of Nebraska-Lincoln

Lindsey Haynes-Maslow ${ }^{\mathrm{d}}$

North Carolina State University

\begin{abstract}
Submitted April 19, 2019 / Revised June 26 and August 11, 2019 / Accepted August 22, 2019 /
Published online February 18, 2020

Citation: DeLonge, M., Robbins, T., Basche, A. D., \& Haynes-Maslow, L. (2020). The state of sustainable agriculture and agroecology research and impacts: A survey of U.S. scientists. Journal of Agriculture, Food Systems, and Community Development, 9(2), 159-184. https://doi.org/10.5304/jafscd.2020.092.009
\end{abstract}

Copyright (C) 2020 by the Authors. Published by the Lyson Center for Civic Agriculture and Food Systems. Open access under CC-BY license.

\begin{abstract}
A growing body of research suggests that although sustainable agriculture, particularly agroecology, can address challenges such as those related to climate change, ecosystem services, food insecurity, and farmer livelihoods, the transition to such sys-

a * Corresponding author: Marcia DeLonge, Food \& Environment Program, Union of Concerned Scientists, Washington, D.C. 20006 USA; +1-510-809-1582; mdelonge@ucsusa.org

b Tali Robbins, Food \& Environment Program, Union of Concerned Scientists.

Robbins is now at the Friedman School of Nutrition Science and Policy, Tufts University; Boston, MA 02111 USA; avital.robbins@tufts.edu

c Andrea D. Basche, Department of Agronomy and Horticulture, University of Nebraska-Lincoln, Lincoln, NE 68583 USA; abasche2@unl.edu

d Lindsey Haynes-Maslow, Department of Agricultural and Human Sciences, North Carolina State University, Raleigh, NC 27695 USA; 1hmaslow@,ncsu.edu
\end{abstract}

tems remains limited. To gain insight into the state of U.S. sustainable agriculture and agroecology, we developed a 28-question mixed-method survey that was administered to scientists in these fields. Respondents $(N=168)$ represented diverse locations, institutions, and career stages. They offered varied definitions of sustainable agriculture, with $40 \%$ considering economic and social well-being to be core components. Respondents identified the amount and duration of public research funding as

\section{Funding Disclosure}

The research was conducted while M.D., T.R., and A.B. were employed by the Union of Concerned Scientists, a nonprofit organization. Funding was provided in part through the generous support of the Grantham Foundation for the Protection of the Environment, the TomKat Foundation, and The New York Community Trust. The funders had no role in the design of the study; in the collection, analyses, and interpretation of data; in the writing of the manuscript; and in the decision to publish the results. 
important obstacles to conducting research on sustainable agriculture ( $85 \%$ and $61 \%$, respectively). Further, most expressed challenges in communicating findings beyond academia, including to the media and policymakers, potentially limiting the impacts of such research. However, respondents expressed satisfaction in several areas, including relationships with community members $(81 \%)$ and local producers $(81 \%)$, and interest from students $(80 \%)$ and research communities $(73 \%)$, suggesting positive momentum in this field. Earlier versus later career scientists rated research on "human dimensions" as more important, expressed greater concerns over career stability, and were less satisfied with opportunities for policy engagement. Results imply that greater public investments, particularly fostering human dimensions, could support a transition to agroecology and its associated benefits.

\section{Keywords}

Agroecosystem, Policy Engagement, Research Funding, Systems Science, Media, Outreach

\section{Introduction}

Additional sustainable agriculture research and adoption is needed in the U.S. to address persistent challenges that threaten farms, farmers, rural communities, and public health and ecosystem services, including air quality, water supply, and biodiversity (Foley et al., 2011; Nelson et al., 2018). The urgency to transition to a system with greater sustainability has accelerated, as evidence shows that climate change, particularly shifts to more extreme and more variable rainfall, is already exacerbating consequences of practices that lead to soil erosion, water pollution, and risks of flooding and drought (U.S. Global Change Research Program, 2018). Sustainable agriculture, as defined by the U.S. Department of Agriculture (USDA), should reduce such undesirable outcomes through a system that will broadly "satisfy human food and fiber needs; enhance environmental quality and the natural resource base upon which the agriculture economy depends; make the most efficient use of nonrenewable resources and on-farm resources and integrate, where appropriate, natural biological cycles and controls; sustain the economic viability of farm operations; and enhance the quality of life for farmers and society as a whole" (National Agricultural Research, Extension, and Technical Policy Act, 1997, p. 9).

The field of agroecology has recently been attracting growing attention for its valuable approaches toward developing more sustainable agriculture (High Level Panel of Experts on Food Security and Nutrition [HLPE], 2019). While agroecology has in some contexts been understood to be most relevant to crop production and practices at the farm scale, it has increasingly been interpreted as also encompassing environmental, social, economic, ethical, and community development issues (Wezel et al., 2009). As this field has evolved and varied, it has been interpreted as referring to a scientific discipline, an agricultural practice, and/or a social movement (Montenegro de Wit \& Iles, 2016; Wezel et al., 2009). In this study, we focus on the scientific discipline of agroecology, asserting that it entails a systems-based integration of ecological concepts with agricultural practices, while also recognizing that it can be understood as drawing on both the biophysical and social sciences (DeLonge \& Basche, 2017; Gliessman, 2015).

As a scientific discipline, agroecology has recently shown that practices such as diversifying farms and rotating crops can deliver positive environmental outcomes at a variety of scales and levels, building soil health locally and protecting water resources more broadly, while maintaining profitable and resilient farms (DeLonge \& Basche, 2017; Gliessman, 2015). For example, a growing body of research has demonstrated measurable improvements in ecosystem services across a range of climates, geographic regions, and agricultural conditions (Altieri, Nicholls, Henao, \& Lana, 2015; Hunt, Hill, \& Liebman, 2017; Isbell et al., 2017; Ponisio et al., 2014; Schulte et al., 2017). Furthermore, agroecology's status not only as a science but also as practice and a movement may uniquely position it to transform food and farming systems (Montenegro de Wit \& Iles, 2016; Cacho et al., 2018; Duru, Therond, \& Fares, 2015). Agroecology could play a significant role in ensuring that agricultural and food systems can meet both production and broader sustainability goals (HLPE, 2019; Hunter, Smith, Schipanski, Atwood, \& 
Mortensen, 2017). It has been proposed that a supportive policy environment, informed by agroecological research from field to ecosystem scales, could accelerate a transition to a more sustainable agricultural landscape (DeLonge, Miles, \& Carlisle, 2016; Miles, DeLonge, \& Carlisle, 2017).

As evidence of the potential benefits of agroecology has emerged, more international organizations and institutions have expressed interest in advancing the field, such as the United Nations (Food and Agriculture Organization of the United Nations [FAO], 2018), the International Panel of Experts on Sustainable Food Systems (Frison, 2016), and the government of France (Gonzalez, Thomas, \& Chang, 2018). In the U.S., organizations that include leading scientific societies, public university coalitions, and nonprofit organizations have also begun to acknowledge the interest in agroecology and its potential to solve interconnected food system challenges (American Society of Agronomy [ASA], Crop Science Society of America [CSSA], \& Soil Science Society of America [ASSA], 2016; Association of Public and Landgrant Universities [APLU], 2017; Schonbeck, Jerkins, \& Ory, 2015; USDA National Institute of Food and Agriculture [USDA NIFA], 2018; Union of Concerned Scientists [UCS], 2016). Interest in agroecology and related disciplines has expanded beyond agricultural sciences to entities such as the National Academies of Sciences, Engineering, and Medicine (2019), which have recognized that systems science, transdisciplinary research, and community partnerships are critical to the future of agriculture and the sustainability of our environment.

Research and practice in these disciplines remain relatively rare, however, possibly due to numerous obstacles. The historic underinvestment in agroecology as compared to conventional agriculture may explain a slower pace of research and development improvements (DeLonge et al., 2016; Pimbert \& Moeller, 2018), initiating a feedback cycle in which limited investment leads to slower improvements, contributing to less likelihood of attracting future investment, and so on (Miles et al., 2017). In the U.S., shortage of funding for agroecology has been exacerbated by reduced rates of public investment in agricultural research and development overall at both the federal and state levels, particularly relative to private investment (Pardey, Chan-Kang, Beddow, \& Dehmer, 2015). In addition to difficulties associated with funding, identified obstacles to agroecology research and development include insufficient supporting infrastructure and related cultural obstacles such as siloed departments, programs, and institutions; lack of suitable equipment and technology across the supply chain; and inadequate incentives for complex, collaborative research (Basche et al., 2014; DeLonge \& Basche, 2017; Duru et al., 2015). Agroecology research requires training in interdisciplinary, systems-science approaches, which are relatively rare and difficult to pursue at U.S. research institutions (DeLonge \& Basche, 2017). Other obstacles for advancing agroecology may include institutional practices and norms that fail to support independent science, such as discouraging scientists from communicating their findings to policymakers and shifting resources from work viewed as politically contentious. Recent studies have provided some evidence that such institutional constraints may exist at the USDA (Carter, Goldman, \& Johnson, 2018; USDA Office of Inspector General [USDA OIG], 2018), the primary source for public agricultural research funding in the U.S. However, little attention has been paid to whether such constraints exist at other institutions, such as colleges and universities. Based on the responses in our survey, we found that, collectively, obstacles that are financial, institutional, and cultural threaten to limit the expansion of agroecological science and practices.

Considering the expanding interest in but limited adoption of sustainable agriculture and agroecology research and practice, the goal of this study was to gain a better understanding of opportunities and barriers surrounding these fields in the U.S. We focused on the scientific community, because research, education, and extension critically affect the array of practices and tools available for farmers and ranchers (Miles et al., 2017). Obstacles within the research community may signify, aggravate, or even produce additional obstacles for agricultural operations and development. Alternatively, investment in the research community could lead to new tools, techniques, and trainings, with benefits for farmers, ranchers, and the public. 


\section{Applied Research Methods}

\section{Survey Development and Distribution}

To gain a better understanding of potential opportunities and obstacles for sustainable agriculture and agroecology, we distributed an online survey to researchers and other professionals with advanced degrees (master or doctorate) who have academic or professional experience in fields related to sustainable agriculture (Appendix). The survey was administered through the SurveyMonkey platform (SurveyMonkey, 2018), using a private passwordprotected account. Incomplete responses were collected and saved by SurveyMonkey after the completion of each survey section, but no personally identifying information (including IP addresses) was collected; thus, the study authors could not resend the link to encourage respondents to complete the survey. Responses were stored on SurveyMonkey before being downloaded to a passwordprotected server.

The 28-question survey contained both multiple-choice and open-ended questions regarding respondent experiences with sustainable agriculture and agroecology, including issues related to funding, institutional support, and collegial support and collaboration opportunities. Further demographic questions assessed career stage, geographic region, and institutional affiliation. Most multiplechoice questions were based on a 5-point Likert scale. All responses were voluntary.

The survey was peer-reviewed by four experts as part of the internal development process. The survey was then submitted to Western IRB, an independent company accredited to perform institutional review board (IRB) services and was approved for an exemption from IRB review (WIRB Work Order \#1-1000684-1). The study team circulated the survey broadly, using active email listservs with interests pertaining to sustainable agriculture and agroecology, ${ }^{1}$ as well as to the Union of Concerned Scientists Science Network members with relevant expertise in agricultural or environmental science. (The Science Network is a network of more than 20,000 individuals with advanced degrees in a diverse range of scientific fields.) We used a snowball recruiting method in which respondents were encouraged to share the survey with other interested and qualified individuals in their professional networks (Heckathorn, 2011). Recruiting emails were first distributed in March 2017. Follow-up requests were sent once to each listserv in mid-April 2017. The survey was closed at the end of April 2017.

\section{Data Analysis}

The original data were downloaded from the SurveyMonkey platform and exported to Microsoft Excel. The data were analyzed using Microsoft Excel and the R software platform (R Core Team, 2014). We evaluated survey results overall, as well as in subgroups for earlier and later career stages. Respondents varied widely in the number of years they have been working in the field, with several respondents identifying in each of the ranges provided in the survey. We analyzed data in this paper using two large groups derived from these ranges: 0 to 10 years (earlier career stage) and 11 or more years (later career stage). These groups capture earlier- and later-career stages, while also representing a relatively balanced number of respondents. We also explored evaluating differences among other subgroups, including region and institution types. However, sample sizes for such groups were not large enough to adequately measure statistical significance.

For questions that included a 5-point Likert scale, 5 represented for respondents the most agreement, satisfaction, or importance, and 1 represented the least agreement, satisfaction, or importance. From these values, we calculated the mean and standard errors of responses. We tested for statistical differences between groups using paired two-sided t-tests in $\mathrm{R}$ statistical software.

Responses to open-ended questions were evaluated qualitatively by a content analysis approach, which involves an analysis of written statements to help identify themes pertaining to a specific topic. For the analysis, we developed a list of key themes and evaluated written responses for the presence or

\footnotetext{
1 The listservs were susag-community@iastate.edu, divfarmingsystems@lists.berkeley.edu, agroecommunity@googlegroups.com, comfood@elist.tufts.edu, NWAEGInternational@umich.edu, nsac-research-extensioneducationcommittee@googlegroups.com
} 
absence of each theme. Content analysis was considered an appropriate approach to open-ended responses because it allows researchers to also code themes that may not have already been established as key themes (Guest, MacQueen, \& Namey, 2011). Relevant codes were identified and defined by two coders. One coder analyzed the full dataset, and a subset of the open-ended content was analyzed independently by two coders to ensure consistency; codes were compared to reconcile discrepancies.

\section{Results}

\section{Survey Respondents}

A total of 168 qualified experts participated in the survey, of whom 165 provided answers to at least one open-ended question, and 104 provided answers to at least one quantitative question. Respondents represented a wide geographic range in the U.S.; diverse positions at academic, nonprofit, private, governmental, and other institutions; and both earlier and later career stages (Table 1).

Respondents who identified their geographic region were relatively dispersed throughout the six U.S. regions. Given the relatively balanced regional distribution as well as the limited number of respondents per region, we did not explore the influence of region on responses in this study. Only 72 respondents specified their job title. We categorized these into two groups: research positions, including doctoral students, post-doctoral fellows, adjunct professors, assistant professors, associate professors, and full professors; and administrative, project coordination and/or management positions. Among the 72 respondents, 62 self-identified as researcher and 10 self-identified as administrative, project coordination and/or management position. The majority of respondents who identified their employer were from a landgrant university ("the term used to identify a public university in each state that was originally established as a land grant college of agriculture pursuant to the Morrill Act of 1862" [Womach, 2005, p. 151]). Thus, these represent a network of U.S. educational institutions that receive federal support and work in collaboration with the USDA to advance agricultural science. Given the lack of respondents within other major employer categories, we did not explore differences between employer subgroups in this paper.

\section{Defining Sustainable Agriculture}

Respondents provided varied definitions of sustainable agriculture. The most common themes identified were related to social viability and wellbeing (included in $40 \%$ of responses), economics $(40 \%)$, and the enhancement of natural resources $(26 \%)$. Other themes appearing in a relatively large percentage of responses included biological diver-

Table 1. Characteristics of Survey Participants: Career Stage and Employer Type

\begin{tabular}{llrr}
\hline & & \multicolumn{2}{c}{ Participants } \\
\cline { 2 - 4 } Category & Subgroup & $(n)$ & $(\%)$ \\
\hline Years in career, $n=73$ & $<1$ & 6 & 8.2 \\
& 1 to 3 & 4 & 5.5 \\
& 4 to 5 & 12 & 16.4 \\
& 6 to 10 & 12 & 16.4 \\
& 11 to 20 & 18 & 22.7 \\
\hline Employer, $n=62$ & $>20$ & 21 & 28.8 \\
& Land Grant University & 40 & 66.7 \\
& Other College or University & 5 & 8.3 \\
& Non-profit organization & 5 & 8.3 \\
& Private industry & 6 & 10.0 \\
& Local, state, or federal government agency & 4 & 6.7 \\
\hline
\end{tabular}


sity (19\%), equity and justice (15\%), ecology (13\%), reducing environmental damage $(15 \%)$, and local considerations $(12 \%)$. Other less common themes, mentioned by less than $10 \%$ of respondents, included regeneration, improving efficiency, connecting consumers and producers, climate adaptation or mitigation, alternative markets, organic practices, and population growth. Theme frequencies were similar between the full group (165 respondents) and the smaller subset that included only respondents who replied to quantitative questions (104 respondents).

Topics of Importance within Sustainable Agriculture Respondents indicated that they consider a range of topics to be important to include in USDA Requests for Applications (RFAs) for research grant proposals (Table 2). Agroecology was ranked as very important (mean score of at least 4 out of a possible 5) by the largest percentage of respondents $(44 \%)$. The majority of proposed areas received an average score of at least 3.3.

\section{Overall perception of obstacles to sustainable agriculture} research and their broader impacts

A large majority of respondents considered several obstacles to be important (Likert scale $=4$ ) or very important (Likert scale $=5$ ) in attempting to perform sustainable agriculture research (Figure 1).
The obstacles substantially consisted of ingrained financial interests and a lack of research funding. Overall, fewer respondents considered obstacles such as conflicts of interest related to the private sector, lack of career stability, and lack of institutional support to be important.

\section{Experiences with sustainable agriculture research}

Respondents cited high levels of satisfaction in many areas of their work in sustainable agriculture (Figure 2). Relationships were a major area of satisfaction, with most respondents indicating positive relationships with local producers (the area with the highest level of satisfaction), interest from students and others seeking mentorship (ranked second), as well as interest from local or regional community members (ranked third).

Respondents were less satisfied with other aspects of their work, including the lesser amount of interdisciplinary, farmer-driven, and communitybased research that they were able to conduct. While the reasons for this could not be gleaned from the quantitative data, the open-ended question indicated that difficulties with building relationships, institutional support, and having enough time were factors experienced as barriers, especially for community-based research. Other areas of low satisfaction were related to the lack of opportunities to engage with policymakers, the media, and

Table 2. Importance for Requests for Applications to Reference Range of Topics in Sustainable Agriculture

\begin{tabular}{|c|c|c|c|c|c|c|c|c|}
\hline \multirow[b]{2}{*}{ Topic in USDA research grant RFAs } & \multirow[b]{2}{*}{$n$} & \multicolumn{6}{|c|}{$\%$} & \multirow{2}{*}{$\begin{array}{c}\text { Standard } \\
\text { Error }\end{array}$} \\
\hline & & 1 & 2 & 3 & 4 & 5 & Mean & \\
\hline Broader public impacts (e.g. ecosystem services) & 91 & 1 & 7 & 19 & 33 & 41 & 4.1 & 0.1 \\
\hline Agroecology & 89 & 3 & 7 & 16 & 30 & 44 & 4.0 & 0.1 \\
\hline Interdisciplinary & 90 & 3 & 8 & 17 & 30 & 42 & 4.0 & 0.1 \\
\hline Human dimensions/decision making & 88 & 6 & 7 & 22 & 27 & 39 & 3.9 & 0.1 \\
\hline Pollinator health & 89 & 3 & 10 & 24 & 29 & 34 & 3.8 & 0.1 \\
\hline Social justice & 86 & 6 & 14 & 14 & 29 & 37 & 3.8 & 0.1 \\
\hline Integrated pest management & 89 & 5 & 15 & 21 & 33 & 27 & 3.6 & 0.1 \\
\hline Economics & 91 & 2 & 14 & 30 & 28 & 26 & 3.6 & 0.1 \\
\hline Racial equity & 87 & 8 & 14 & 21 & 26 & 31 & 3.6 & 0.1 \\
\hline Organic production systems & 90 & 8 & 16 & 22 & 29 & 26 & 3.5 & 0.1 \\
\hline Perennial crops & 86 & 7 & 14 & 28 & 27 & 24 & 3.5 & 0.1 \\
\hline Crop rotation & 90 & 4 & 26 & 20 & 30 & 20 & 3.4 & 0.1 \\
\hline Improved grazing systems & 88 & 11 & 13 & 27 & 28 & 21 & 3.3 & 0.1 \\
\hline Agroforestry & 87 & 8 & 21 & 24 & 26 & 21 & 3.3 & 0.1 \\
\hline
\end{tabular}


the wider public. The only area where dissatisfaction was greater than satisfaction was in respondent perceived opportunities to engage with policymakers.

Experiences with obstacles in sustainable agriculture research

Respondents did not agree that a variety of hypothesized potential obstacles to sustainable agriculture research affected their work (Figure 3). For 10 of 12 statements suggesting potential obstacles, few respondents agreed that they reflected actual barriers to their work. The statement that received the lowest level of agreement was, "I have experienced pressure to modify research results." However, $58 \%$ of respondents agreed (including 15\% who strongly agreed) with the statement, "Sustainable agriculture

\section{Figure 1. Perceptions of Obstacles to Sustainable Agriculture Research $(N=71)$}

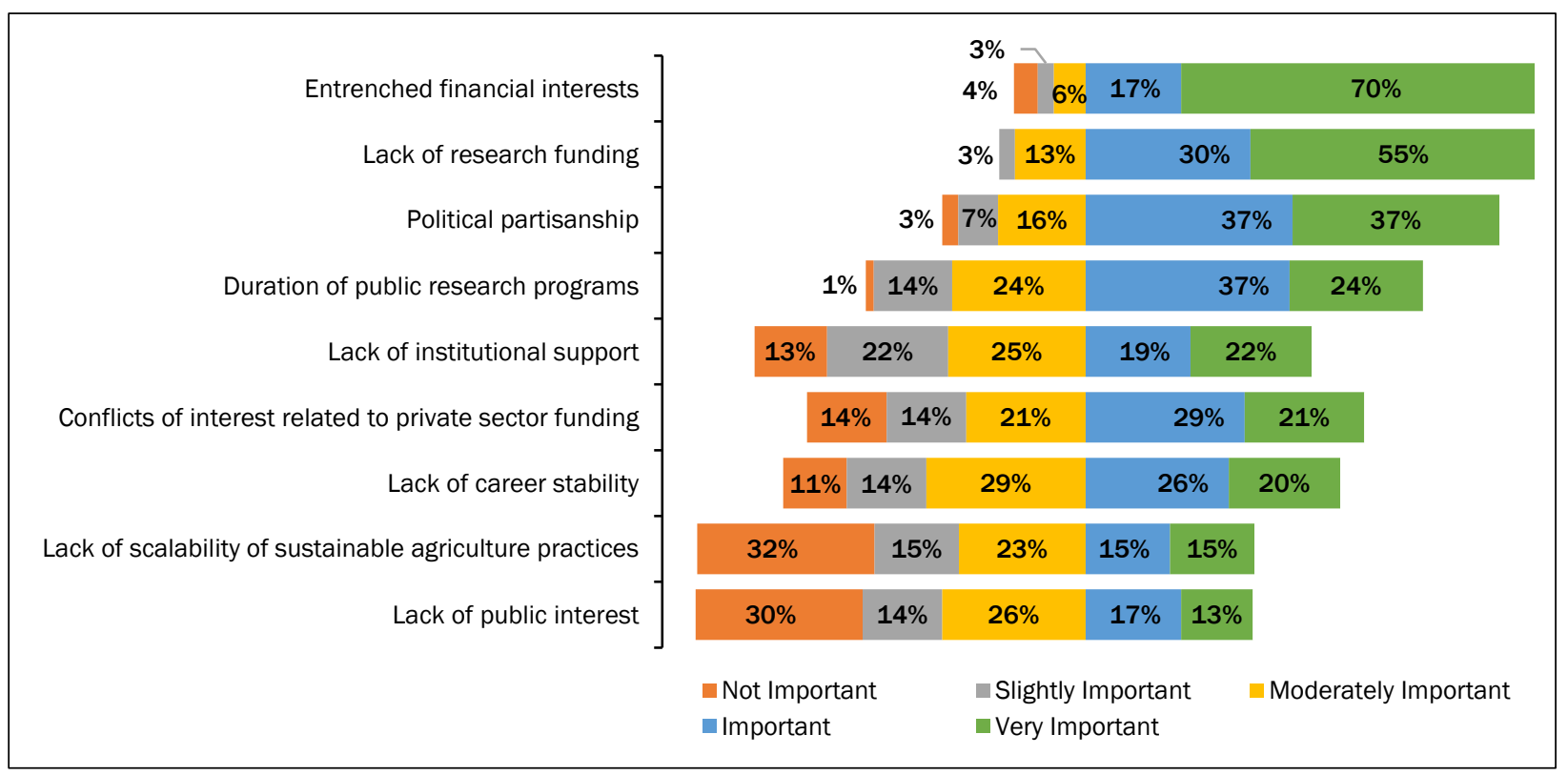

Figure 2. Level of Satisfaction in Areas of Sustainable Agriculture Research ( $N=87$ )

\begin{tabular}{|c|c|c|c|c|c|c|c|c|}
\hline Positive relationships with local/regional community members & \multicolumn{5}{|c|}{$1 \% 3 \% 25 \%$} & $44 \%$ & & $27 \%$ \\
\hline Positive relationships with local producers & \multicolumn{5}{|c|}{$1 \% 5 \% 14 \%$} & $43 \%$ & & $37 \%$ \\
\hline Interest from students and/or others seeking mentorship & \multicolumn{5}{|c|}{$1 \% 5 \% 14 \%$} & $44 \%$ & & $36 \%$ \\
\hline Interest from your disciplinary research community & \multicolumn{5}{|c|}{$4 \% \quad 8 \% 15 \%$} & & $8 \%$ & $15 \%$ \\
\hline Support from colleagues at your institution & \multicolumn{3}{|r|}{$3 \%$} & $16 \% \quad 1$ & $17 \%$ & \multicolumn{2}{|c|}{$47 \%$} & $18 \%$ \\
\hline Opportunities for community-based research-stakeholder engagement & \multicolumn{2}{|r|}{$6 \%$} & $15 \%$ & $34 \%$ & & $31 \%$ & $14 \%$ & \\
\hline Opportunities for media attention or public communication & \multicolumn{2}{|r|}{$5 \%$} & $16 \%$ & $34 \%$ & & $33 \%$ & $11 \%$ & \\
\hline Amount of on-farm (participatory farmer) research you are able to conduct & \multicolumn{2}{|r|}{$4 \%$} & $21 \%$ & $34 \%$ & & $28 \%$ & $14 \%$ & \\
\hline Level of interdisciplinary research you are able to conduct & & $4 \%$ & $22 \%$ & 24 & $4 \%$ & $39 \%$ & $11 \%$ & \\
\hline Support from your institution & & $6 \%$ & $20 \%$ & 25 & $5 \%$ & $34 \%$ & $14 \%$ & \\
\hline Opportunities to engage with policymakers & $15 \%$ & $28 \%$ & & $41 \%$ & & $14 \% 3 \%$ & & \\
\hline & $\begin{array}{l}\text { y Dissa } \\
\text { ther Se } \\
\text { y Satis }\end{array}$ & $\begin{array}{l}\text { atisfied } \\
\text { atisfied nc } \\
\text { fied }\end{array}$ & or Dissati & tisfied & & $\begin{array}{l}\text { issatisfied } \\
\text { atisfied }\end{array}$ & & \\
\hline
\end{tabular}


research entails challenging relationships with agricultural stakeholders." Open-ended responses in this section of the survey reinforced concerns regarding lack of institutional support, challenges with funding, and external pressure to change their research agenda.

\section{Experiences with policy engagement and the media: A closer look}

To gain a better understanding of respondent experiences specifically related to policy engagement, the survey asked them to indicate the degree to which policy engagement was part of their job, and whether it was important or should be avoided. To this question, $73 \%$ of respondents considered policy engagement to be important, whereas just $26 \%$ stated that policy engagement is part of their job $(n=70)$.

Respondents were also asked to state their degree of satisfaction with various aspects of policy engagement in their work (Figure 4). Results indicated that a large portion of respondents was satisfied with the number of students interested in policy engagement. Many respondents were also satisfied or very satisfied with the number of colleagues interested in policy engagement and the support they receive from colleagues. Just $17 \%$ of respondents were satisfied with the amount of training they had received for policy engagement, and no respondents were very satisfied in this area. While not specified within the survey, satisfaction in terms of rewards and recognition could be interpreted in a variety of ways, including financial, acknowledgment, or career advancement. None of the respondents were very satisfied with the amount of time they had for policy engagement.

\section{Influence of Career Stage}

Our results show that career stage may influence perceptions of obstacles and opportunities involving sustainable agriculture research (Table 3). First, earlier-career scientists (defined as those working between 0 and 10 years in the field) were more

\section{Figure 3. Experience with Obstacles in Sustainable Agriculture Research $(N=71)$}

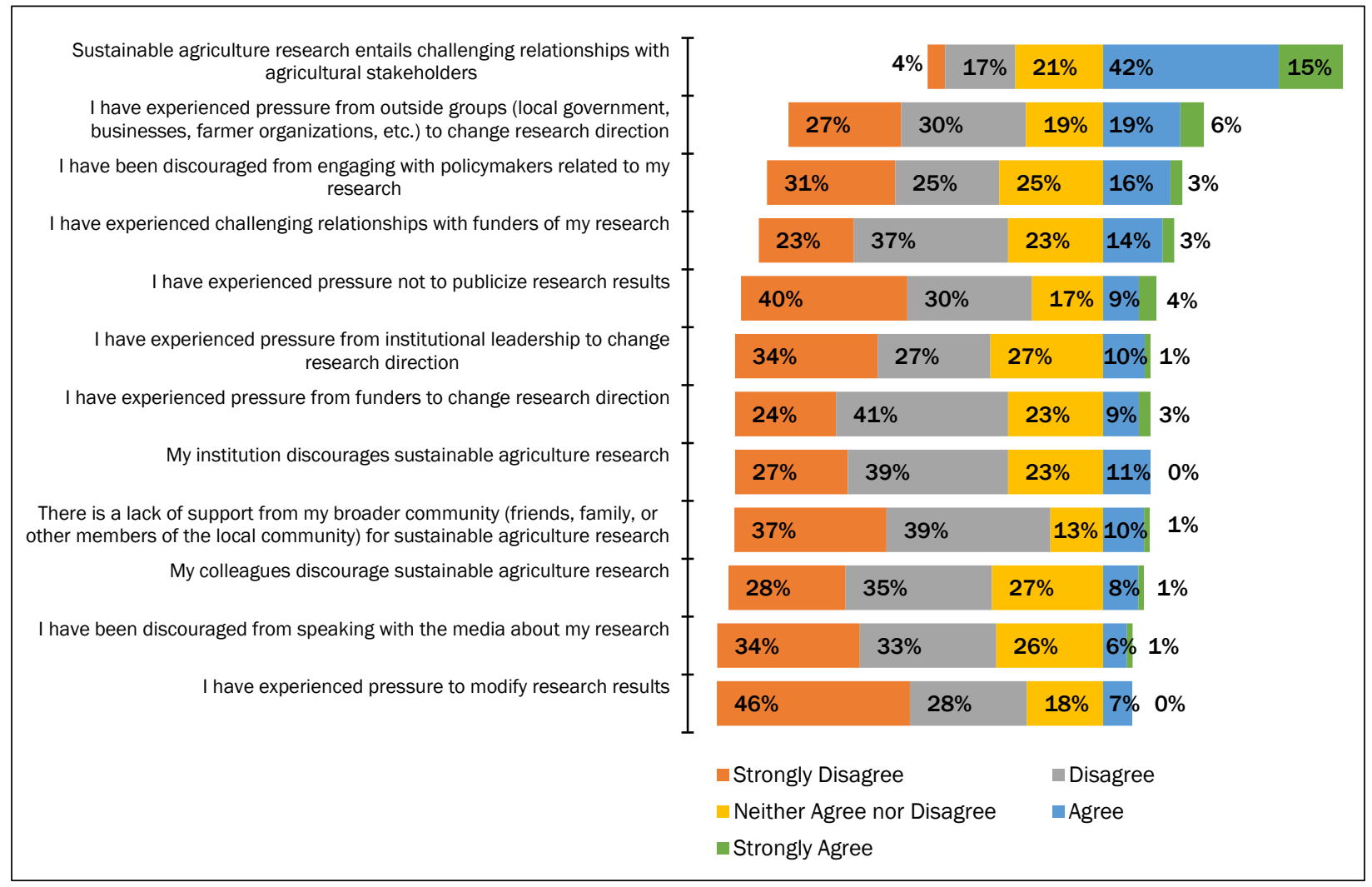


Figure 4. Satisfaction with Policy Engagement on the Topic of Sustainable Agriculture $(N=61)$

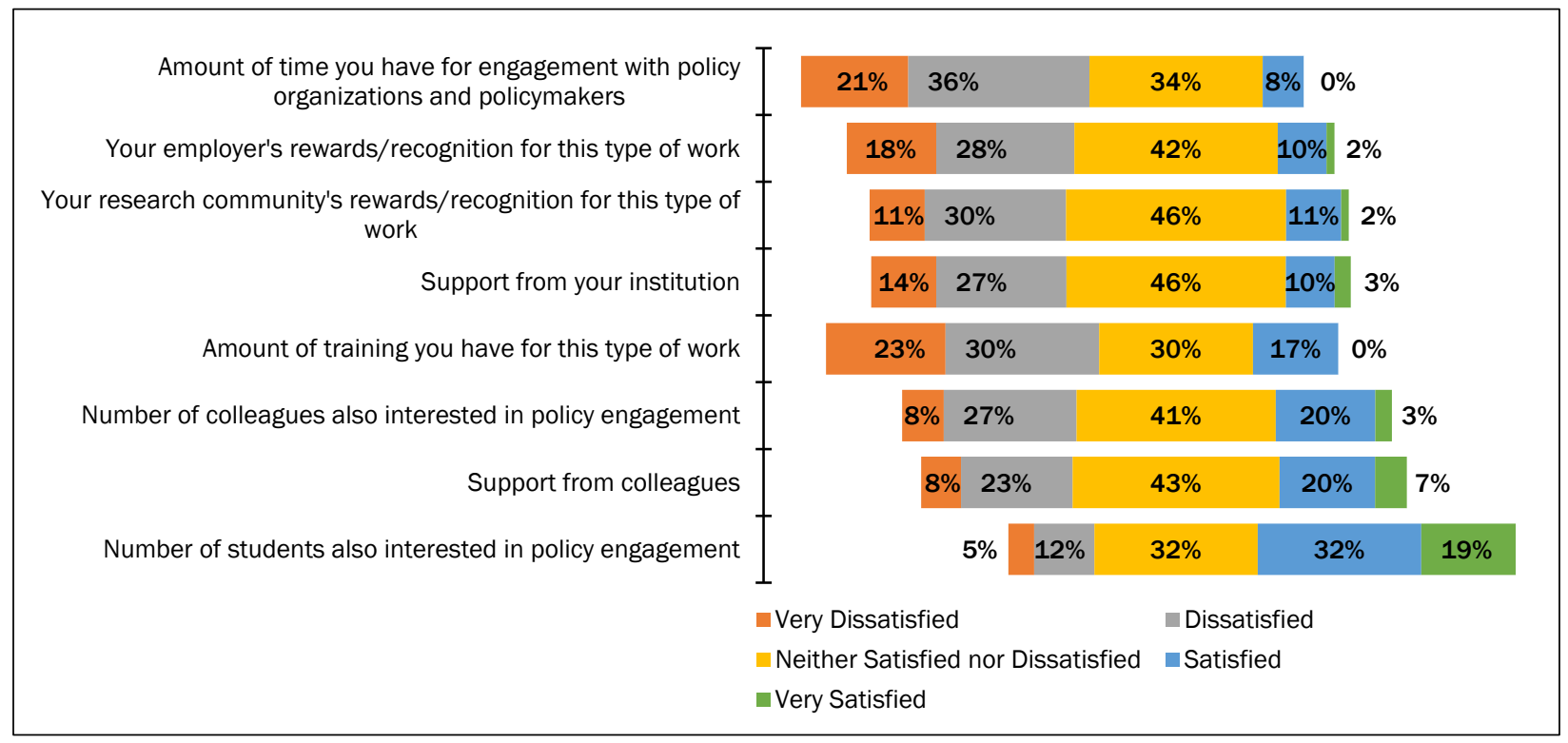

Table 3. Areas of Select Survey Questions Where Career Stage Influenced Responses

\begin{tabular}{lccc}
\hline Topic/Question & $\begin{array}{c}\text { Earlier Career } \\
\text { (0-10 years) }\end{array}$ & $\begin{array}{c}\text { Later Career } \\
\text { (> 10 years) }\end{array}$ & $p$-value \\
\hline RFA: Agroforestry (Table 2) & 2.923 & 3.500 & 0.082 \\
RFA: Economics (Table 2) & 3.933 & 3.286 & 0.016 \\
RFA: Human dimensions/decisionmaking (Table 2) & 4.214 & 3.514 & 0.024 \\
RFA: Organic production systems (Table 2) & 3.138 & 3.667 & 0.081 \\
Lack of career stability (Table 3) & 3.677 & 2.921 & 0.010 \\
Amount of time for engagement with policy organizations and policymakers & 2.042 & 2.485 & 0.079 \\
(Table 6) & 2.125 & 2.594 & 0.089 \\
Amount of training received for this type of work (policy) (Table 6) & & & \\
\hline
\end{tabular}

likely to identify human dimensions/decisionmaking and economics as relatively important topics for research grant RFAs $(p<0.05)$. However, later-career scientists identified organic production systems and agroforestry as relatively more important topics $(p<0.10)$. Earlier- and later-career scientists also exhibited differences with respect to policy engagement. Earlier-career scientists were less satisfied on average with both the time they had for engagement with policy organizations and the amount of training they received for this type of work $(\phi<0.10)$. In terms of obstacles, earliercareer scientists identified lack of career stability as a relatively more important obstacle as compared to all other respondents $(p=0.01)$.

\section{Discussion}

Research Investment as a Lever for Transitioning to a More Sustainable Agriculture System

Our results provided further evidence that research in sustainable agriculture, including agroecology, is underfunded, given current needs. In our survey, $85 \%$ of respondents cited lack of funding as an important obstacle to sustainable agriculture research. Several comments in open-ended responses made a similar point. These results are consistent with quantitative analyses of funding sources, which have shown limited public investment in agroecology compared with conventional agriculture (DeLonge et al., 2016; Pimbert \& 
Moeller, 2018). In the U.S., the severity of the disproportional funding is pronounced due to the declining prioritization of public funding for agricultural research in recent decades (Pardey et al., 2015), hindering the ability of sustainable agriculture practitioners to develop and apply their research findings on a wider scale. This survey also highlighted the unique importance of independent public funding, as a large majority (87\%) of respondents agreed that financial interests present important or very important obstacles to their work. Despite the need for public and independent agricultural research funding, it has been estimated that nearly one-quarter of funding at land grant universities comes from private industry, potentially discouraging research that is critical of private industries or that prioritizes advancing a broader public benefit (Food \& Water Watch, 2012).

Investing in research is a lever for the transition to agroecology, not only through the quantity of funding but also through the scope and structure of funding programs. A majority of survey respondents $(61 \%)$ indicated that the insufficient duration of long-term financial support is a barrier to the complex, systems-based research required in this field. In addition, respondents largely agreed that USDA RFAs should encourage agroecology directly while also prioritizing several areas that are critical to advancing agroecology, such as research promoting broad public benefits, interdisciplinary approaches, social justice, and racial equity. It is also worth noting that a large fraction of respondents included both social and biophysical elements in their definitions of sustainable agriculture, which emphasizes the importance of transdisciplinary work as a foundation for continuing progress and defining crucial aspects of agroecology. Based on these findings, several programmatic changes could be adopted within grant programs that would better support scientists and other stakeholders working in sustainable agriculture, agroecology, and related fields.

\section{Relationships as a Foundation for Opportunities and as Obstacles in Sustainable Agriculture}

Relationships are both a positive factor in and an obstacle to sustainable agriculture research. For example, relationships were an area in which researchers felt the most satisfaction with their work, and our results indicated that there is widespread interest in sustainable agriculture and agroecology, including among students, colleagues, and other stakeholders, particularly for interdisciplinary, farmer-driven, and community-based research. On the other hand, agreement with the statement "Sustainable agriculture research entails challenging relationships with agricultural stakeholders" represented the strongest consensus of any question in our survey. Although the question did not specify further details, such challenges may involve relations with stakeholder groups, including farmers and farm organizations, industry organizations (e.g., suppliers of inputs such as fertilizers and pesticides), and other community groups.

While our study did not ask respondents to go into detail regarding challenging relationships, the survey results may imply difficult dynamics that tend to reinforce existing power structures and circumstances that are challenging to confront or alter. Such institutional dynamics were highlighted as an obstacle to agricultural change in a recent policy analysis from the United Kingdom and France (Gonzalez et al., 2018). Similar research has noted how universities and industry have become intertwined, leading to complex relationships that often focus more on revenue generation than on pursuing research in the public interest (Glenna, Lacy, Welsh, \& Biscotti, 2007; Welsh. Glenna, Lacy, \& Biscotti, 2008). More transparency and equity may help to resolve such relationship challenges (Chiles, 2018).

\section{Fostering Science Communication and Broader Impacts}

Given the relative scarcity of public research funding as well as the presence of tenuous relationships in sustainable agriculture research, it is important that funded research is widely communicated both within and beyond academia. However, our results suggest that although many experts are interested in applying their research to inform agricultural policy and public dialogue, they report difficulties in doing so. Difficulties include lack of training and support from their institutions, indicating possible tension between scientists and their employers concerning the freedom to engage in policy. The time available to do such work was also a theme that 
emerged in responses to open-ended and multiplechoice questions in our survey, suggesting that incentives could be shifted such that researchers prioritize the time needed to do this work. To facilitate scientists engaging in policymaking, universities could adopt measures toward reducing the stigma surrounding policy engagement or even proactively affirm their support for affiliated researchers to engage with the policy process. Likewise, universities, research institutions, and competitive grant programs could further emphasize outreach and extension and improve training and support for media and public outreach. Effective channels of communication could help researchers share their findings to improve transparency and understanding, and to facilitate implementation and success of sustainable agricultural production systems. This is of particular importance for earliercareer researchers, who are both interested in policymaking and dissatisfied with current training opportunities and available time. In addition, earlier-career scientists are more likely to report concern about career stability, and greater training and incentives for policy engagement and communication could particularly support those in less stable career stages.

Concrete affirmations for the importance of broader impacts of sustainable agriculture are especially important in a political environment in which federal government scientists face heightened scrutiny and workloads. In a recent survey of government scientists, more than $90 \%$ of USDA scientists had noticed workforce reductions and $92 \%$ stated that such reductions made it more difficult for the agency to fulfill its science-based mission (Carter et al., 2018). Moreover, more than one-third of USDA scientists had noticed that resources had been allocated away from work viewed as politically contentious (Carter et al., 2018). When political interference may constrain the ability of federal scientists from communicating with policymakers, it is all the more important for researchers at universities and other independent institutions to maintain the freedom to do so.

\section{Study Limitations}

It is important to note that our study had some limitations. For example, the survey was designed to target a relatively narrow population of interest (U.S. scientists engaged in sustainable agriculture and agroecology research), and this limited the potential sample size. In terms of sampling, we used a snowball recruitment method to target this narrow population without strictly limiting the survey's reach (as an invite-only approach would have done). This approach enabled us to collect a sample of interest, but not an ideal representative random sample.

Furthermore, as with all voluntary surveys, the results of this survey are based on the responses from individuals who were both most likely to receive the survey and motivated to invest the time to complete the survey. Thus the results are subject to associated response and nonresponse errors; that is, those that chose not to complete the survey might have different perceptions than those that did complete it.

Another limitation was that our survey questions were voluntary. We chose to allow survey respondents to decide which questions to answer in an effort to encourage completion of as many questions as respondents were comfortable with. The consequence of this design was that it reduced our sample size for many of the questions, thereby limiting the scope of our analysis, particularly with respect to statistical testing for differences between groups.

\section{Conclusions}

Our survey of scientists working in the field of sustainable agriculture indicated that there is great interest and support for related topics, including agroecology. However, the survey also revealed numerous obstacles that may be limiting the advancement of research, extension, and education. These include not only the amount and scope of available research funding, but also lack of training, time, support for communicating findings outside of academic circles, as well as challenging relationships with agricultural interests holding power. Thus, encouraging and preparing researchers to share the results of their work, including through media and policy engagement, may be an important lever to enhancing the transition to a more sustainable agriculture system. Given respondents' understanding of 
agroecology as a transdisciplinary practice that encompasses both biophysical and social sciences, stronger support for agroecology research could enable researchers and other stakeholders to address real-world problems related to human well-being and persistent inequities in the food system.

\section{Acknowledgments}

For their thoughtful reviews and feedback during the development of the survey, the authors would like to thank four anonymous reviewers. We would also like to thank three anonymous JAFSCD reviewers for their helpful suggestions that substantially improved this article.

\section{References}

Altieri, M. A., Nicholls, C. I., Henao, A., \& Lana, M. A. (2015). Agroecology and the design of climate change-resilient farming systems. Agronomy for Sustainable Development, 35, 869-890. https://doi.org/10.1007/s13593-015-0285-2

American Society of Agronomy [ASA], Crop Science Society of America [CSSA], \& Soil Science Society of America [ASSA]. (2016). The food-energy-water nexus in agronomy, crop and soil sciences. Madison, WI: Authors. Retrieved from https://www.crops.org/files/science-policy/letters/2016-02-04-infews-summary.pdf

Association of Public and Land-grant Universities. (2017). The challenge of change: Harnessing university discovery, engagement, and learning to achieve food and nutrition security. Washington, D.C.: Author. Retrieved from https://www.aplu.org/members/councils/presidents/presidentsdocuments/6-2017/challenge-of-changematerial.pdf

Basche, A. D., Roesch-McNally, G. E., Pease, L. A., Eidson, C. D., Lahdou, G. B., Dunbar, M. W., ... Wilke, A. K. (2014). Challenges and opportunities in transdisciplinary science: The experience of next generation scientists in an agriculture and climate research collaboration. Journal of Soil and Water Conservation, 69(6), 176A-179A. https://doi.org/10.2489/jswc.69.6.176A

Cacho, M. M. y. T. G., Giraldo, O. F., Aldasoro, M., Morales, H., Ferguson, B. G., Rosset, P., ...\& Campos, C. (2018). Bringing agroecology to scale: Key drivers and emblematic cases. Agroecology and Sustainable Food Systems, 42(6), 637665. https://doi.org/10.1080/21683565.2018.1443313

Carter, J., Goldman, G., \& Johnson, C. (2018). Science under President Trump: Voices of scientists across 16 federal agencies. Cambridge, MA: Union of Concerned Scientists. Retrieved from https://www.ucsusa.org/sites/default/files/attach/2018/08/science-under-trump-report.pdf

Chiles, R. M., Glenna, L., Sharma, A., Catchmark, J., Azzara, C. D., \& Maretzki, A. (2018). Agri-food firms, universities, and corporate social responsibility: What's in the public interest? Renewable Agriculture and Food Systems. Advance online publication. https://doi.org/10.1017/S1742170518000376

DeLonge, M., \& Basche, A. (2017). Leveraging agroecology for solutions in food, energy, and water. Elementa, Science of the Antbropocene, 5, 6. https://doi.org/10.1525/elementa.211

DeLonge, M. S., Miles, A., \& Carlisle, L. (2016). Investing in the transition to sustainable agriculture. Environmental Science \& Policy, 55(Part 1), 266-273. https://doi.org/10.1016/j.envsci.2015.09.013

Duru, M., Therond, O., \& Fares, M. (2015). Designing agroecological transitions: A review. Agronomy for Sustainable Development, 35, 1237-1257. https://doi.org/10.1007/s13593-015-0318-x

Foley, J. A., Ramankutty, N., Brauman, K. A., Cassidy, E. S., Gerber, J. S., Johnston, M., ... \& Zaks, D. P. M. (2011). Solutions for a cultivated planet. Nature, 478, 337-342. https://doi.org/10.1038/nature10452

Food and Agriculture Organization of the United Nations [FAO]. (2018). Agroecology can help change the world's food production for the better: Calls for transformative change at 2nd International Agroecology Symposium in Rome. Rome: Author. Retrieved from http://www.fao.org/news/story/en/item/1113475/icode/

Food \& Water Watch. (2012). Public research, private gain: Corporate influence over university agriculture. Washington, D.C.: Author. Retrieved from https://www.foodandwaterwatch.org/insight/public-research-private-gain

Frison, E. (2016). From uniformity to diversity: A paradigm shift from industrial agriculture to diversified agroecological systems. Indian Journal of Plant Genetic Resources, 29(3), 237-240. https://doi.org/10.5958/0976-1926.2016.00033.4

Glenna, L. L., Lacy, W. B., Welsh, R., \& Biscotti, D. (2007). University administrators, agricultural biotechnology, and academic capitalism: Defining the public good to promote university-industry relationships. The Sociological Quarterly, 48(1), 141-163. https://doi.org/10.1111/j.1533-8525.2007.00074.x 
Gliessman, S. (2016). Transforming food systems with agroecology. Agroecology and Sustainable Food Systems, 40(3), 187189. https://doi.org/10.1080/21683565.2015.1130765

Gonzalez, R. A., Thomas, J., \& Chang, M. (2018). Translating agroecology into policy: The case of France and the United Kingdom. Sustainability, 10(8), 2930. https://doi.org/10.3390/su10082930

Guest, G., MacQueen, K. M., \& Namey, E. E. (2011). Applied thematic analysis. Thousand Oaks, CA: Sage.

Heckathorn, D. D. (2011). Comment: Snowball versus respondent-driven sampling. Sociological Methodology, 41(1), 355366. https://doi.org/10.1111/j.1467-9531.2011.01244.x

High Level Panel of Experts on Food Security and Nutrition [HLPE]. (2019). Agroecological and other innovative approaches for sustainable agriculture and food systems that enhance food security and nutrition (HLPE Report 14). Rome: FAO, Committee on World Food Security. Retrieved from http://www.fao.org/agroecology/database/detail/en/c/1242141/

Hunt, N. D., Hill, J. D., \& Liebman, M. (2017). Reducing freshwater toxicity while maintaining weed control, profits, and productivity: Effects of increased crop rotation diversity and reduced herbicide usage. Environmental Science \& Technology, 51(3), 1707-1717. https://doi.org/10.1021/acs.est.6b04086

Hunter, M. C., Smith, R. G., Schipanski, M. E., Atwood, L. W., \& Mortensen, D. A. (2017). Agriculture in 2050: Recalibrating targets for sustainable intensification. BioScience, 67(4), 386-391. https://doi.org/10.1093/biosci/bix010

Isbell, F., Adler, P. R., Eisenhauer, N., Fornara, D., Kimmel, K., Kremen, C., ... \& Scherer-Lorenzen, M. (2017). Benefits of increasing plant diversity in sustainable agroecosystems. Journal of Ecology, 105(4), 871-879. https://doi.org/10.1111/1365-2745.12789

Miles, A., DeLonge, M. S., \& Carlisle, L. (2017). Triggering a positive research and policy feedback cycle to support a transition to agroecology and sustainable food systems. Agroecology and Sustainable Food Systems, 41(7), 855-879. https://doi.org/10.1080/21683565.2017.1331179

Montenegro de Wit, M., \& Iles, A. (2016). Toward thick legitimacy: Creating a web of legitimacy for agroecology. Elementa: Science of the Anthropocene, 4, 000115. https://doi.org/10.12952/journal.elementa.000115

National Academies of Sciences, Engineering, and Medicine. (2019). Science breakthroughs to advance food and agricultural research by 2030. Washington, D.C.: National Academies Press. https://doi.org/10.17226/25059

National Agricultural Research, Extension, and Teaching Policy Act (NARETPA). (1977). Pub L. No. 95-1137, Ti. XIV Subti. AS 1404(17). Retrieved from https://nifa.usda.gov/sites/default/files/resource/nar77.pdf

Nelson, G., Bogard, J., Lividini, K., Arsenault, J., Riley, M., Sulser, T. B., ... \& Rosegrant, M. (2018). Income growth and climate change effects on global nutrition security to mid-century. Nature Sustainability, 1, 773-781. https://doi.org/10.1038/s41893-018-0192-z

Pardey, P. G., Chan-Kang, C., Beddow, J. M., \& Dehmer, S. P. (2015). Long-run and global R\&D funding trajectories: The U.S. Farm Bill in a changing context. American Journal of Agricultural Economics, 97(5), 1312-1323. https://doi.org/10.1093/ajae/aav035

Pimbert, M. P., \& Moeller, N. I. (2018). Absent agroecology aid: On UK agricultural development assistance since 2010. Sustainability, 10(2), 505. https://doi.org/10.3390/su10020505

Ponisio, L. C., M’Gonigle, L. K., Mace, K. C., Palomino, J., de Valpine, P., \& Kremen, C. (2014). Diversification practices reduce organic to conventional yield gap. Proceedings of the Royal Society B: Biological Sciences, 282(1799), 20141396. https://doi.org/10.1098/rspb.2014.1396

R Core Team. (2014). R: A language and environment for statistical computing. Vienna: R Foundation for Statistical Computing. http://www.R-project.org/

Schonbeck, M., Jerkins, D., \& Ory, J. (2016). Taking stock: Analyzing and reporting organic research investments, $2002-2014$. Santa Cruz, CA: Organic Farming Research Association. Retrieved from https://ofrf.org/wp-content/uploads/2019/11/WholeTakingStockReport V3.pdf

Schulte, L. A., Niemi, J., Helmers, M. J., Liebman, M., Arbuckle, J. G., James, D. E ... \& Witte, C. (2017). Prairie strips improve biodiversity and the delivery of multiple ecosystem services from corn-soybean croplands. Proceedings of the National Academy of Sciences, 114(42), 11247-11252. https://doi.org/10.1073/pnas.1620229114

SurveyMonkey. (2018). San Mateo, CA: SVMK Inc. https://www.surveymonkey.com/ 
Union of Concerned Scientists [UCS]. (2016). Scientists call for public investment in agroecological research. Cambridge, MA: Author. Retrieved from https://www.ucsusa.org/our-work/food-agriculture/solutions/advance-sustainableagriculture/scientists-call-public-investment-agroecology

U.S. Department of Agriculture [USDA] National Institute of Food and Agriculture [NIFA]. (2018). NIFA listens: Investing in science to transform lives. What we heard in 2017. Washington, D.C.: USDA NIFA. Retrieved from https://nifa.usda.gov/nifalistens2017

USDA Office of Inspector General [USDA OIG]. (2018). Survey of USDA scientists regarding scientific integrity: Methodology, analysis, and results (Product No. 16-010-01). Washington, D.C.: Author. https://www.usda.gov/oig/webdocs/16-010-01.pdf

U.S. Global Change Research Program. (2018). Fourth national climate assessment. Volume II: Impacts, risks, and adaptation in the United States. Washington, D.C.: Author. https://nca2018.globalchange.gov

Welsh, R., Glenna, L. L., Lacy, W. B., \& Biscotti, D. (2008). Close enough but not too far: Assessing the effects of university-industry research relationships and the rise of academic capitalism. Research Policy, 37(10), 1854-1864. https://doi.org/10.1016/j.respol.2008.07.010

Wezel, A., Bellon, S., Doré, T., Francis, C., Vallod, D., \& David, C. (2009). Agroecology as a science, a movement and a practice. A review. Agronomy for Sustainable Development, 29(4), 503-515. https://doi.org/10.1051/agro/2009004

Womach, J. (2005). Agriculture: A glossary of terms, programs, and laws, 2005 edition. Washington, D.C.: Library of Congress, Congressional Research Service. Retrieved from https://www.everycrsreport.com/reports/97-905.html 


\section{Appendix. Original Survey Circulated Among Agroecology Experts}

Thank you for participating in our anonymous survey! The survey will take about 15-20 minutes to complete. Please answer all questions as honestly and completely as possible. Answers will be kept completely anonymous and confidential.

This survey is intended for researchers or other professionals with an advanced degree (Master's or Ph.D.) and with academic or professional experience that is relevant to sustainable agricultural systems.

The goal of this survey is to collect information from researchers on their experiences securing funding and conducting research broadly related to a more sustainable agricultural system. The survey contains three sets of questions, related to:

1) securing funding for this type of work

2) researchers' satisfaction with different aspects of sustainable agriculture research and outreach; and

3) institutional challenges to sustainable agriculture research and outreach

If you have questions about the survey or its use, please contact Tali Robbins at trobbins@ucsusa.org.

1. How do you define sustainable agriculture? Your answer may be brief -- a few sentences, phrases, or less. We will use your definition to better understand how definitions of sustainable agriculture vary and to provide greater context for your responses in the following sections.

PART 1 OF 3: FUNDING

Questions are not mandatory, so if a question does not apply to your experience, please feel free to leave it blank. Answers will be saved after the completion of each section.

2. In your current position, on average, how many sustainable agriculture research funding proposals do you write per year? If you have been in your position for more than five years, please just focus on the previous five years.
○ 1-3
○ 4-7
○ $8-10$
$0>10$ 
3. In your current position, please estimate what percentage of your working time is spent writing research proposals for sustainable agriculture. If you have been in your position for more than five years, please focus just on the previous five years.
$0<10 \%$
○ $10-25 \%$
○ $25-50 \%$
○ $50-75 \%$
○ $>75 \%$

4. For each agency listed below, please indicate whether you have submitted at least one research proposal related to sustainable agriculture (relevant to your current position, as either Principal or Co-Investigator) and whether it was fully funded, partially funded, and/or did not receive funding, within the last five years.

\begin{tabular}{|l|l|l|l|l|l|l|}
\hline & \multicolumn{2}{|c|}{ Principal Investigator } & \multicolumn{2}{c|}{ Co-Principal Investigator } \\
\hline & $\begin{array}{c}\text { Fully } \\
\text { funded }\end{array}$ & $\begin{array}{c}\text { Partially } \\
\text { funded }\end{array}$ & $\begin{array}{c}\text { Submitted, } \\
\text { Not funded }\end{array}$ & $\begin{array}{c}\text { Fully } \\
\text { funded }\end{array}$ & $\begin{array}{c}\text { Partially } \\
\text { funded }\end{array}$ & $\begin{array}{c}\text { Submitted, } \\
\text { Not funded }\end{array}$ \\
\hline $\begin{array}{l}\text { National Science } \\
\text { Foundation }\end{array}$ & & & & & & \\
\hline $\begin{array}{l}\text { U.S. Department of } \\
\text { Agriculture-SARE }\end{array}$ & & & & & & \\
\hline USDA - AFRI & & & & & & \\
\hline USDA - other & & & & & & \\
\hline $\begin{array}{l}\text { U.S. Environmental } \\
\text { Protection Agency }\end{array}$ & & & & & & \\
\hline $\begin{array}{l}\text { U.S. Department of } \\
\text { Energy }\end{array}$ & & & & & & \\
\hline $\begin{array}{l}\text { Industry - private } \\
\text { companies }\end{array}$ & & & & & & \\
\hline $\begin{array}{l}\text { Industry- commodity } \\
\text { organizations }\end{array}$ & & & & & & \\
\hline Foundations & & & & & & \\
\hline Non-profits & & & & & & \\
\hline $\begin{array}{l}\text { State Department of } \\
\text { Agriculture }\end{array}$ & & & & & & \\
\hline $\begin{array}{l}\text { State Department of } \\
\text { Natural Resources }\end{array}$ & & & & & & \\
\hline Other (please specify). & & & & & & \\
\hline
\end{tabular}

5. Are there any funding programs that you have applied to in the past but have abandoned due to the low funding rates or apparent research direction of the funding program?
O Yes
○ Unsure
○ No

If applicable, please add examples. 
6. Over the course of your career, acquiring funding for sustainable agriculture research has become:
○ Much easier
○ Easier
O About the same
O Harder
O Much harder

7. Regarding USDA research grants, how important is it for Requests for Applications (RFAs) to explicitly reference the following topics related to the broader field of sustainable agriculture? Please consider both existing and potential future RFAs.

\begin{tabular}{|l|l|l|l|l|l|}
\hline & $\begin{array}{c}\text { 1- not } \\
\text { important }\end{array}$ & $\begin{array}{c}\text { 2- slightly } \\
\text { important }\end{array}$ & $\begin{array}{c}\text { 3-fairly } \\
\text { important }\end{array}$ & 4- important & $\begin{array}{c}\text { 5- very } \\
\text { important }\end{array}$ \\
\hline Agroecology & & & & & \\
\hline Agroforestry & & & & & \\
\hline $\begin{array}{l}\text { Broader public impacts (i.e. } \\
\text { ecosystem services) }\end{array}$ & & & & & \\
\hline Crop rotations & & & & & \\
\hline Economics & & & & & \\
\hline $\begin{array}{l}\text { Human dimensions/ } \\
\text { decisionmaking }\end{array}$ & & & & & \\
\hline Improved grazing systems & & & & & \\
\hline Integrated pest management & & & & & \\
\hline Interdisciplinary & & & & & \\
\hline Organic production systems & & & & & \\
\hline Perennial crops & & & & & \\
\hline Pollinator health & & & & & \\
\hline Racial equity & & & & & \\
\hline Social justice & & & & & \\
\hline Other (please specify). & & & & & \\
\hline
\end{tabular}

8. Aside from changing Request for Applications (RFA) language, how important are the following changes to USDA research grant programs to better support sustainable agriculture research?

\begin{tabular}{|l|c|c|c|c|c|}
\hline & $\begin{array}{c}\text { 1- not } \\
\text { important }\end{array}$ & $\begin{array}{c}\text { 2- slightly } \\
\text { important }\end{array}$ & $\begin{array}{c}\text { 3-fairly } \\
\text { important }\end{array}$ & $\begin{array}{c}4- \\
\text { important }\end{array}$ & $\begin{array}{c}\text { 5- very } \\
\text { important }\end{array}$ \\
\hline $\begin{array}{l}\text { Increasing the duration of } \\
\text { research grants }\end{array}$ & & & & & \\
\hline $\begin{array}{l}\text { Increasing maximum } \\
\text { funding amounts per grant }\end{array}$ & & & & & \\
\hline Other (please specify) & \multicolumn{5}{|l|}{} \\
\hline
\end{tabular}


9. Regarding non-USDA research grants, how important is it for Requests for Applications (RFAs) to explicitly reference the following topics related to the broader field of sustainable agriculture?

\begin{tabular}{|l|c|c|c|c|c|}
\hline & $\begin{array}{c}\text { 1-not } \\
\text { important }\end{array}$ & $\begin{array}{c}\text { 2- slightly } \\
\text { important }\end{array}$ & $\begin{array}{c}\text { 3-fairly } \\
\text { important }\end{array}$ & $\begin{array}{c}4- \\
\text { important }\end{array}$ & $\begin{array}{c}\text { 5-very } \\
\text { important }\end{array}$ \\
\hline Agroecology & & & & & \\
\hline Agroforestry & & & & & \\
\hline $\begin{array}{l}\text { Broader public impacts (i.e. } \\
\text { ecosystem services) }\end{array}$ & & & & & \\
\hline Crop rotations & & & & & \\
\hline Economics & & & & & \\
\hline $\begin{array}{l}\text { Human dimensions/ } \\
\text { decisionmaking }\end{array}$ & & & & & \\
\hline Improved grazing systems & & & & & \\
\hline Integrated pest management & & & & & \\
\hline Interdisciplinary & & & & & \\
\hline Organic production systems & & & & & \\
\hline Perennial crops & & & & & \\
\hline Pollinator health & & & & & \\
\hline Racial equity & & & & & \\
\hline Social justice & & & & & \\
\hline Other (please specify) & & & & & \\
\hline
\end{tabular}

10. Aside from changing Request for Application (RFA) language, how important are the following changes to non-USDA research grants?

\begin{tabular}{|l|c|c|c|c|c|}
\hline & $\begin{array}{c}\text { 1- not } \\
\text { important }\end{array}$ & $\begin{array}{c}\text { 2- slightly } \\
\text { important }\end{array}$ & $\begin{array}{c}\text { 3-fairly } \\
\text { important }\end{array}$ & 4-important & $\begin{array}{c}\text { 5-very } \\
\text { important }\end{array}$ \\
\hline $\begin{array}{l}\text { Increasing the duration of } \\
\text { research grants }\end{array}$ & & & & & \\
\hline $\begin{array}{l}\text { Increasing maximum } \\
\text { funding amount per grant }\end{array}$ & & & & & \\
\hline Other (please specify) & \multicolumn{5}{|l|}{} \\
\hline
\end{tabular}

\section{PART 2 OF 3: RESEARCH \& OUTREACH}

Questions are not mandatory, so if a question does not apply to your experience, please feel free to leave it blank. Answers will be saved after the completion of each section. 
11. In your overall research experience working on sustainable agriculture research, please rate your level of satisfaction with each of the following areas:

\begin{tabular}{|l|l|l|l|l|l|}
\hline & $\begin{array}{c}1 \text { - very } \\
\text { dissatisfied }\end{array}$ & $\begin{array}{c}2- \\
\text { dissatisfied }\end{array}$ & $\begin{array}{c}\text { 3-neither } \\
\text { satisfied nor } \\
\text { dissatisfied }\end{array}$ & 4-satisfied & $\begin{array}{c}\text { 5-very } \\
\text { satisfied }\end{array}$ \\
\hline $\begin{array}{l}\text { Support from your } \\
\text { institution }\end{array}$ & & & & \\
\hline $\begin{array}{l}\text { Support from colleagues at } \\
\text { your institution }\end{array}$ & & & & & \\
\hline $\begin{array}{l}\text { Interest from your } \\
\text { disciplinary research } \\
\text { community }\end{array}$ & & & & & \\
\hline $\begin{array}{l}\text { Interest from students } \\
\text { and/or others seeking } \\
\text { mentorship }\end{array}$ & & & & \\
\hline $\begin{array}{l}\text { Positive relationships with } \\
\text { local producers }\end{array}$ & & & & \\
\hline $\begin{array}{l}\text { Positive relationships with } \\
\text { local/regional community } \\
\text { members }\end{array}$ & & & & & \\
\hline $\begin{array}{l}\text { Level of interdisciplinary } \\
\text { research you are able to do }\end{array}$ & & & & & \\
\hline $\begin{array}{l}\text { The amount of on-farm } \\
\text { (participatory farmer) } \\
\text { research you are able to do }\end{array}$ & & & & & \\
\hline $\begin{array}{l}\text { Opportunities for } \\
\text { community-based } \\
\text { research-stakeholder } \\
\text { engagement }\end{array}$ & & & & & \\
\hline $\begin{array}{l}\text { Opportunities for media } \\
\text { attention or public } \\
\text { communication }\end{array}$ & & & & & \\
\hline $\begin{array}{l}\text { Opportunities to engage } \\
\text { with policymakers }\end{array}$ & & & & & \\
\hline
\end{tabular}


12. Regarding your experience with interdisciplinary research, please rate your satisfaction with the following elements of your work and the work of your institution:

\begin{tabular}{|l|l|l|l|l|l|}
\hline $\begin{array}{l}\text { Number of colleagues willing } \\
\text { to participate }\end{array}$ & $\begin{array}{c}\text { 1-very } \\
\text { dissatisfied }\end{array}$ & $\begin{array}{c}2- \\
\text { dissatisfied }\end{array}$ & $\begin{array}{c}\text { 3-neither satisfied } \\
\text { nor dissatisfied }\end{array}$ & $\begin{array}{c}4- \\
\text { satisfied }\end{array}$ & $\begin{array}{c}5 \text {-very } \\
\text { satisfied }\end{array}$ \\
\hline $\begin{array}{l}\text { Number of students willing to } \\
\text { participate }\end{array}$ & & & & & \\
\hline Support from your institution & & & & & \\
\hline $\begin{array}{l}\text { Institutional commitment to } \\
\text { hiring interdisciplinary } \\
\text { scientists }\end{array}$ & & & & & \\
\hline Amount of funding available & & & & & \\
\hline $\begin{array}{l}\text { Ease of managing funds } \\
\text { between collaborators }\end{array}$ & & & & & \\
\hline $\begin{array}{l}\text { Amount of time investment } \\
\text { required to win grants for this } \\
\text { type of research, as compared } \\
\text { to your other research }\end{array}$ & & & & & \\
\hline $\begin{array}{l}\text { Amount of time you have for } \\
\text { this type of research }\end{array}$ & & & & & \\
\hline $\begin{array}{l}\text { The amount of training you } \\
\text { have for this type of research }\end{array}$ & & & & & \\
\hline $\begin{array}{l}\text { Institutional rewards/ } \\
\text { promotion/recognition for this } \\
\text { type of research }\end{array}$ & & & & & \\
\hline
\end{tabular}

13. Please add any comments regarding the amount of interdisciplinary research that you conduct.

14. Please add any comments regarding your satisfaction with your institution's commitment to interdisciplinary research. 
15. Regarding your experience with on-farm or farmer-participatory research, please rate your level of satisfaction with the following elements of your work and the work of your institution:

\begin{tabular}{|l|l|l|l|l|l|}
\hline & $\begin{array}{c}1 \text { - very } \\
\text { dissatisfied }\end{array}$ & $\begin{array}{c}\text { 2- } \\
\text { dissatisfied }\end{array}$ & $\begin{array}{c}\text { 3-neither } \\
\text { satisfied nor } \\
\text { dissatisfied }\end{array}$ & 4-satisfied & $\begin{array}{c}\text { 5-very } \\
\text { satisfied }\end{array}$ \\
\hline $\begin{array}{l}\text { The number of colleagues } \\
\text { willing to participate }\end{array}$ & & & & & \\
\hline $\begin{array}{l}\text { The number of students willing } \\
\text { to participate }\end{array}$ & & & & & \\
\hline Support from your institution & & & & & \\
\hline $\begin{array}{l}\text { The amount of funding } \\
\text { available }\end{array}$ & & & & & \\
\hline $\begin{array}{l}\text { Ease of managing funds } \\
\text { between collaborators }\end{array}$ & & & & & \\
\hline $\begin{array}{l}\text { The amount of time to write } \\
\text { grants for this type of research }\end{array}$ & & & & & \\
\hline $\begin{array}{l}\text { The amount of time you have } \\
\text { for this type of research }\end{array}$ & & & & & \\
\hline $\begin{array}{l}\text { The amount of training you } \\
\text { have for this type of research }\end{array}$ & & & & & \\
\hline $\begin{array}{l}\text { Institutional rewards/ } \\
\text { promotion/recognition for this } \\
\text { type of research }\end{array}$ & & & & & \\
\hline
\end{tabular}

16. Please add any additional comments regarding your satisfaction with your experience with on-farm or farmer-participatory research.

17. Regarding your experience with community-based research (i.e., research topics developed with stakeholders in the community), please rate your level of satisfaction with:

\begin{tabular}{|l|l|l|l|l|l|}
\hline & $\begin{array}{c}1 \text {-very } \\
\text { dissatisfied }\end{array}$ & $\begin{array}{c}2- \\
\text { dissatisfied }\end{array}$ & $\begin{array}{c}\text { 3-neither } \\
\text { satisfied nor } \\
\text { dissatisfied }\end{array}$ & $\begin{array}{c}4- \\
\text { satisfied }\end{array}$ & $\begin{array}{c}5 \text {-very } \\
\text { satisfied }\end{array}$ \\
\hline $\begin{array}{l}\text { The number of colleagues willing to } \\
\text { participate }\end{array}$ & & & & & \\
\hline $\begin{array}{l}\text { The number of students willing to } \\
\text { participate }\end{array}$ & & & & & \\
\hline Support from your institution & & & & & \\
\hline The amount of funding available & & & & & \\
\hline $\begin{array}{l}\text { Ease of managing funds between } \\
\text { collaborators }\end{array}$ & & & & & \\
\hline $\begin{array}{l}\text { The amount of time to write grants for this } \\
\text { type of research }\end{array}$ & & & & & \\
\hline $\begin{array}{l}\text { The amount of time you have for this type } \\
\text { of research }\end{array}$ & & & & & \\
\hline $\begin{array}{l}\text { The amount of training you have for this } \\
\text { type of research }\end{array}$ & & & & & \\
\hline $\begin{array}{l}\text { Institutional rewards/promotion/ } \\
\text { recognition for this type of research }\end{array}$ & & & & & \\
\hline
\end{tabular}


18. Please add any additional comments regarding your level of satisfaction with your experiences with community-based research.

19. In your experience with media and public outreach, please rate your level of satisfaction with:

\begin{tabular}{|l|l|l|l|l|l|}
\hline & $\begin{array}{c}\text { 1-very } \\
\text { dissatisfied }\end{array}$ & $\begin{array}{c}2- \\
\text { dissatisfied }\end{array}$ & $\begin{array}{c}\text { 3-neither } \\
\text { satisfied } \\
\text { nor } \\
\text { dissatisfied }\end{array}$ & 4-satisfied & $\begin{array}{c}\text { 5-very } \\
\text { satisfied }\end{array}$ \\
\hline $\begin{array}{l}\text { Support/encouragement from } \\
\text { colleagues }\end{array}$ & & & & & \\
\hline Support from your institution & & & & & \\
\hline $\begin{array}{l}\text { The amount of time you have for } \\
\text { these activities }\end{array}$ & & & & & \\
\hline $\begin{array}{l}\text { The amount of training you have for } \\
\text { these activities }\end{array}$ & & & & & \\
\hline $\begin{array}{l}\text { Institutional rewards/ promotion/ } \\
\text { recognition for this type of research }\end{array}$ & & & & & \\
\hline $\begin{array}{l}\text { Your research community's rewards/ } \\
\text { recognition for these activities }\end{array}$ & & & & & \\
\hline
\end{tabular}

20. Please add any additional comments regarding your level of satisfaction with media and public outreach opportunities.

21. Please indicate the degree to which policy engagement is a part of your job.

O Policy engagement is not part of your job, and should be avoided

- Policy engagement is not part of your job, but can be appropriate

O Policy engagement is not technically part of your job, but is important

- Policy engagement is part of your job, but you prefer avoid it

$\circ$ Policy engagement is part of your job, and is important 
22. In your experience with policy engagement on the topic of sustainable agriculture, please rate your level of satisfaction with:

\begin{tabular}{|l|l|l|l|l|l|}
\hline & $\begin{array}{c}\text { 1-very } \\
\text { dissatisfied }\end{array}$ & 2-dissatisfied & $\begin{array}{c}\text { 3-neither } \\
\text { satisfied nor } \\
\text { dissatisfied }\end{array}$ & $\begin{array}{c}\text { 4- } \\
\text { satisfied }\end{array}$ & $\begin{array}{c}\text { 5-very } \\
\text { satisfied }\end{array}$ \\
\hline $\begin{array}{l}\text { The number of colleagues also } \\
\text { interested in policy engagement } \\
\text { opportunities }\end{array}$ & & & & & \\
\hline $\begin{array}{l}\text { The number of students also } \\
\text { interested in policy engagement } \\
\text { opportunities }\end{array}$ & & & & & \\
\hline $\begin{array}{l}\text { Support/encouragement from } \\
\text { colleagues }\end{array}$ & & & & & \\
\hline Support from your institution & & & & & \\
\hline $\begin{array}{l}\text { The amount of time you have for } \\
\text { engagement with policy } \\
\text { organizations and policy makers }\end{array}$ & & & & & \\
\hline $\begin{array}{l}\text { The amount of training you have } \\
\text { for this type of work }\end{array}$ & & & & & \\
\hline $\begin{array}{l}\text { Your employer's rewards/ } \\
\text { recognition for this type of work }\end{array}$ & & & & & \\
\hline $\begin{array}{l}\text { Your research community's } \\
\text { rewards/recognition for these } \\
\text { activities }\end{array}$ & & & & & \\
\hline
\end{tabular}

23. Please add any additional comments you have regarding your level of satisfaction with your policy engagement experience.

\section{PART 3 OF 3: OBSTACLeS tO RESEARCH}

Questions are not mandatory, so if a question does not apply to your experience, please feel free to leave it blank. Answers will be saved after the completion of each section.

24. Please rate your level of agreement with the following statements regarding obstacles you may have faced through your sustainable agriculture research

\begin{tabular}{|l|l|l|l|l|l|}
\hline & $\begin{array}{c}\text { 1-strongly } \\
\text { disagree }\end{array}$ & $\begin{array}{c}\text { 2- } \\
\text { disagree }\end{array}$ & $\begin{array}{c}\text { 3-neither } \\
\text { agree nor } \\
\text { disagree }\end{array}$ & 4-agree & $\begin{array}{c}\text { 5-strongly } \\
\text { agree }\end{array}$ \\
\hline $\begin{array}{l}\text { My institution discourages sustainable } \\
\text { agriculture research }\end{array}$ & & & & & \\
\hline $\begin{array}{l}\text { My colleagues discourage sustainable } \\
\text { agriculture research }\end{array}$ & & & & & \\
\hline $\begin{array}{l}\text { There is a lack of support from my broader } \\
\text { community (friends, family, or other } \\
\text { members of local community) for } \\
\text { sustainable agriculture research }\end{array}$ & & & & & \\
\hline $\begin{array}{l}\text { Sustainable agriculture research entails } \\
\text { challenging relationships with agricultural }\end{array}$ & & & & & \\
\hline
\end{tabular}




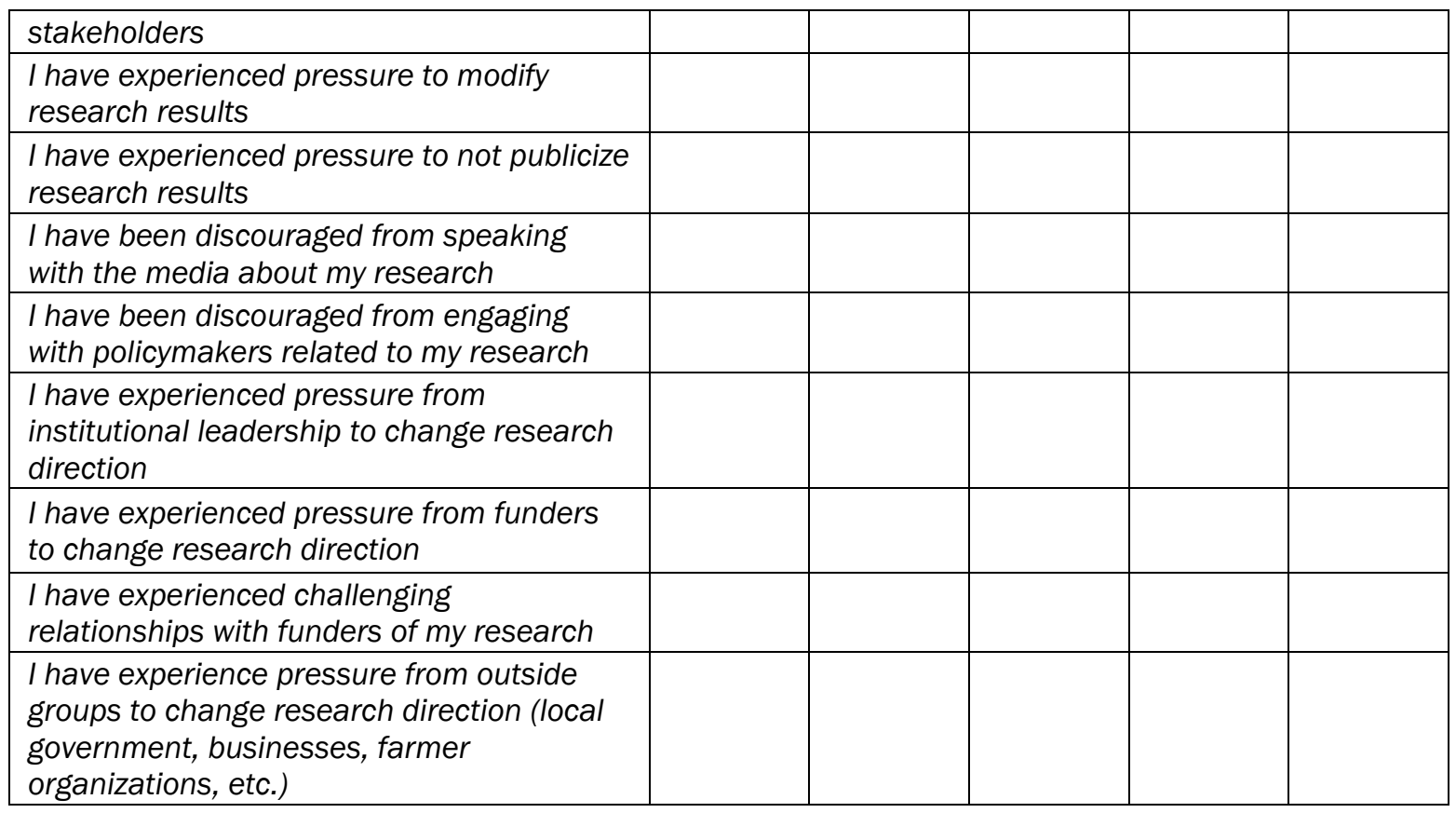

25. Please add any additional comments you may have regarding these challenges.

26. In your opinion, how important are the following obstacles to sustainable agriculture research?

\begin{tabular}{|l|l|l|l|l|l|}
\hline & $\begin{array}{c}\text { 1-not } \\
\text { important }\end{array}$ & $\begin{array}{c}\text { 2- slightly } \\
\text { important }\end{array}$ & $\begin{array}{c}\text { 3-moderately } \\
\text { important }\end{array}$ & 4-important & $\begin{array}{c}\text { 5-very } \\
\text { important }\end{array}$ \\
\hline Political partisanship & & & & & \\
\hline Entrenched financial interests & & & & & \\
\hline Lack of research funding & & & & & \\
\hline Lack of career stability & & & & & \\
\hline $\begin{array}{l}\text { Conflicts of interest related to } \\
\text { private sector funding }\end{array}$ & & & & & \\
\hline $\begin{array}{l}\text { Direction of public research } \\
\text { programs }\end{array}$ & & & & & \\
\hline Lack of public interest & & & & & \\
\hline Lack of institutional support & & & & & \\
\hline $\begin{array}{l}\text { Lack of scalability of } \\
\text { sustainable agriculture } \\
\text { practices }\end{array}$ & & & & & \\
\hline Other (please specify) & & & & & \\
\hline
\end{tabular}

27. If you could share a story with decision makers (i.e. policy makers or agency leadership) on the need for more funding for sustainable agriculture, what would you say?

28. Do you have any other comments regarding sustainable agriculture funding or other obstacles to sustainable agriculture research that you would like to share? 


\section{CONCLUSION: BACKGROUND INFORMATION}

Questions are not mandatory, so if a question does not apply to your experience, please feel free to leave it blank. Answers will be saved after the completion of each section.

29. Which best describes your title? Check all that apply.
$\square$ Assistant Professor
$\square$ Associate Professor
$\square$ Professor
$\square$ Adjunct Professor
$\square$ Department Chair
$\square$ Dean or other administrative role
$\square$ Extension Appointment
$\square$ Researcher/Research Associate
$\square$ Post-doctoral Fellow/Researcher
$\square$ Program/Project Manager
$\square$ Policy Coordinator
$\square$ Development Coordinator
$\square$ Outreach Coordinator
$\square$ Other (please specify)

30. What is the highest education level you have completed?
O Bachelor's degree
O Master's degree
o Ph.D.
O Non-U.S. degree/ other (please specify)

31. At which type of institution do you currently work? Check all that apply.
$\square$ Land Grant University
$\square$ Other (Non-Land Grant) Public University
$\square$ Private University
$\square$ Community College
$\square$ Federal government
$\square$ State or local government
$\square$ Non-profit organization
$\square$ Private Industry
$\square$ Other (please specify)

32. What is your area of expertise (i.e. current department or graduate major)?

$\square$ Primary field of expertise:

$\square$ Secondary field of expertise: 
33. For how many years have you been working in your current position?
$0<1$
○ $1-3$
○ $4-5$
○ $6-10$
○ $11-20$
$0>20$

34. For how many years have you been working in your current field of study (excluding graduate school)?
$0<1$
○ 1-3
○ 4-5
○ 6-10
○ $11-20$
○ $>20$

35. In what region of the United States are you currently based?
- N/A- outside of the United States
- Southwest (including CA)
- Pacific Northwest (including AK)
o Northern Plains
- Southern Plains
○ Midwest
O Southeast
○ Northeast 